Ethos : Jurnal Penelitian dan Pengabdian kepada Masyarakat, Vol 7, No.2, Juni 2019: 200-209

\title{
PENGELOLAAN KOTA MELALUI JEJARING SISTER CITY: KASUS STUDI DARI INDONESIA
}

\author{
${ }^{1}$ Gina Puspitasari Rochman \\ ${ }^{1}$ Universitas Islam Bandung, Bandung, Jawa Barat, Indonesia \\ E-mail: 'Iginapuspitasaripl23@gmail.com
}

\begin{abstract}
Previous research has examined global cities networks by means of the sister city cooperations and the factors which influence its implementation. However, there is no research which examines the extent to which these factors influence the success of sister city cooperation. Therefore, investigating the success factors of the sister city cooperation that contribute to city management is carried out. The case study approach is used by applying in-depth interviews to key informants for subsequent coding and content analysis. We found that the reciprocal relations accurring between the two cities are main factors which spur the sister city cooperation so that it led to the improvement of human resources, helped reduce problems in managing the city environment, and triggered increased market opportunities and global competitiveness. This condition is also supported by consistent local leadership. Meanwhile, shared interests and community participation are needed as a prerequisite for a development process and cooperation relationships that do not directly affect the success of the cooperation.
\end{abstract}

Keywords: sister city networks, cooperation, success, city management, Indonesia

\begin{abstract}
Abstrak. Penelitian sebelumnya telah banyak memeriksa jejaring kota - kota di dunia melalui kemitraan sister city dan faktor - faktor yang berpengaruh terhadap pelaksanaannya. Namun, belum ada penelitian menyeluruh yang memeriksa sejauh mana faktor-faktor tersebut berpengaruh terhadap kemitraan sister city. Untuk itu, investigasi terhadap faktor - faktor kesuksesan kemitraan sister city yang dapat berkontribusi terhadap pengelolaan kota dilakukan. Pendekatan studi kasus digunakan dengan menerapkan wawancara mendalam terhadap informan kunci untuk selanjutnya dilakukan proses pengkodean dan analisis isi. Kami menemukan bahwa hubungan timbal balik yang terjadi antara kedua kota menjadi faktor utama yang memicu kemitraan sister city sehingga mengarah pada peningkatan sumber daya manusia, membantu mengurangi masalah pengelolaan lingkungan kota, serta memicu peningkatan peluang pasar dan daya saing global. Kondisi tersebut ditunjang juga oleh kepemimpinan lokal yang konsisten. Sementara itu, kepentingan bersama dan partisipasi masyarakat dibutuhkan sebagai prasyarat dari suatu proses pembangunan dan hubungan kemitraan yang tidak berpengaruh langsung terhadap kesuksesan kemitraan.
\end{abstract}

Kata kunci: jejaring sister city, kemitraan, kesuksesan, pengelolaan kota, Indonesia

\section{Pendahuluan}

Jejaring internasional dibangun kota - kota di dunia sebagai respon terhadap kebutuhan pembangunan, globalisasi, dan desentralisasi. Globalisasi dan desentralisasi memberikan peluang bagi pemerintah di tingkat lokal untuk membangun jejaring internasional sebagai upaya untuk merespon kebutuhan lokal dan meningkatkan daya saing secara global. Pemerintah di tingkat lokal dapat mengakses sumber daya global dan menjadi pemain di tingkat internasional (J. C. De Villiers, 2009; Roldan, 2018). Jejaring ini mulai dibangun sejak tahun 1950-an di negara - negara maju dan 
menyebar ke kota - kota di negara berkembang dan kota - kota industri di dunia melalui kemitraan antar kota. Fenomena ini mengikis perbedaan kewenangan antara pemerintah di tingkat pusat dan lokal (Keating, 1991).

Jejaring sister city merupakan jejaring internasional yang mana dua atau lebih komunitas setidaknya di dua negara bermitra secara jangka panjang melalui pertukaran teknologi, sumber daya, dan pengetahuan, keahlian, serta pembelajaran (M. Bontenbal \& Van Lindert, 2008; Jacobus Christiaan De Villiers, 2011; O’Toole, 2001). Bentuk kemitraan ini merupakan fenomena global. Mulanya, jejaring ini terbentuk dari hubungan persahabatan antara dua kota yang dilatarbelakangi oleh adanya kedekatan secara geografis maupun kesamaan karakteristik kedua kota secara ekonomi, budaya, maupun sejarah (LGIB, 2001; O'Toole, 2001). Kemudian, hubungan tersebut meluas menjadi kerjasama antar kota di berbagai bidang pembangunan yang dilandasi kepentingan dan manfaat bersama untuk membuat kondisi kehidupan kota yang bermitra menjadi lebih baik (M. Bontenbal \& Van Lindert, 2008; Tjandradewi \& Marcotullio, 2009).

Jejaring internasional yang dibangun melalui kemitraan sister city meningkat seiring diterapkannya sistem desentralisasi, termasuk di Indonesia. Kemitraan sister city mampu mempromosikan good governance melalui penguatan pemerintah lokal dan peningkatan kapasitas masyarakat (M. C. Bontenbal, 2009; UNDP, 2000). Sebagaimana terjadi di negara - negara di Eropa, dibangunnya kemitraan sister city dijadikan strategi oleh para pemimpin lokal untuk membangun pemahaman bersama dan mendorong pertumbuhan ekonomi di tingkat lokal dengan memberikan peluang partisipasi publik yang lebih besar (Hafteck, 2003;
LGIB, 2001; O'Toole, 2001; Tjandradewi \& Marcotullio, 2009).

Penelitian sebelumnya, telah memeriksa bahwa kesuksesan kemitraan sister city dipengaruhi faktor - faktor, diantaranya keterbukaan informasi, berbagi biaya, kepemimpinan, hubungan timbal balik, dan partisipasi publik (J. C. De Villiers, 2009; Gomes-Casseres, 1998; Tjandradewi \& Marcotullio, 2009). Selain itu, berdasarkan penelitiannya di Asia, Tjandradewi (2009) menambahkan bahwa kemitraan sister city lebih bermanfaat bagi pemerintah lokal untuk isu - isu lingkungan, pendidikan dan kesehatan, serta sosial budaya dibandingkan isu ekonomi, kemiskinan, dan pembiayaan pembangunan. Namun, penelitian penelitian tersebut belum ada yang memeriksa sejauh mana kemitraan sister city berperan bagi pengelolaan kota, khususnya di negara berkembang. Dengan demikian, artikel ini berupaya menginvestigasi sejauh mana faktor faktor penting pada kemitraan sister city berkontribusi terhadap kesuksesan kemitraan dalam pengelolaan kota.

Sebagai salah satu negara berkembang, Indonesia mulai membangun jejaring internasional melalui kemitraan sister city sejak tahun 1980-an. Namun, tidak sampai 15 persen dari kemitraan tersebut yang berjalan dengan baik dan sisanya berjalan seadanya, bahkan lebih dari 65 persen tidak melakukan kegiatan apapun (Salam, 2004). Kota Surabaya menunjukan pelaksanaan kemitraan sister city yang sukses di bidang lingkungan (Kurniawan, de Oliveira, Premakumara, \& Nagaishi, 2013). Penelitian ini menggunakan pendekatan studi kasus melalui eksplorasi terhadap praktik kemitraan sister city di Kota Surabaya yang dilihat dari proses dan hasil yang berkontribusi terhadap penyediaan dan peningkatan pelayanan 
kota di berbagai bidang pembangunan. Hasil penelitian ini memperkaya literatur mengenai pengelolaan perkotaan dan bermanfaat bagi pemerintah di tingkat lokal dalam menyusun strategi pengelolaan kota melalui kemitraan sister city.

\section{Tinjauan Pustaka}

Kesuksesan kemitraan sister city dipengaruhi oleh kesamaan karakteristik wilayah, kepemimpinan, partisipasi publik, komunikasi atau aliran informasi yang terbuka, dan hubungan timbal balik (J. C. De Villiers, 2009; GomesCasseres, 1998; Tjandradewi \& Marcotullio, 2009). Faktor - faktor tersebut berperan sejak tahap awal penentuan tujuan dan mitra hingga tahap implementasi kegiatan. Pada akhirnya, kepentingan dan manfaat bersama untuk membuat kondisi kehidupan lebih baik menjadi tujuan jangka panjang kemitraan ini (M. Bontenbal \& Van Lindert, 2008; Tjandradewi \& Marcotullio, 2009).

Kesamaan karakteristik wilayah memudahkan terbentuknya kerjasama dan membangun kepentingan bersama yang saling menguntungkan. Kesamaan karakteristik tersebut meliputi kesamaan sejarah; kesamaan tingkat ekonomi, kemiripan nama; keterkaitan yang sudah terjalin sebelumnya, serta kemiripan permintaan sesuai kebutuhan kota (J. C. De Villiers, 2009; Zelinsky, 1991). Kemiripan dan keseteraan antara kedua pihak akan menghilangkan ketergantungan pada salah satu pihak (Tjandradewi \& Marcotullio, 2009). Selain itu, tujuan dan kemampuan yang saling melengkapi menjadi perhatian pihak - pihak dalam menentukan mitranya dengan mempertimbangkan kebutuhan kota (J. C. De Villiers, 2009; Gomes-Casseres, 1998).

Kepemimpinan diinterpretasikan sebagai suatu konsistensi dan sifat kualitas yang dipandang penting dimiliki pemimpin, seperti kecerdasan, kreativitas, diplomasi dan kebijaksanaan, pengetahuan, keterampilan persuasif dan sosial (Stimson, Stough, \& Salazar, 2009; Tjandradewi \& Marcotullio, 2009). Keterampilan ini dinyatakan sebagai aspek penting untuk mengenali masalah nyata dengan turun bertemu orang orang. Kualitas pemimpin ini berpengaruh terhadap tindakan yang mengarah pada solusi, keeratan hubungan kemitraan, dan implementasi program atau kegiatan (Tjandradewi \& Marcotullio, 2009).

Kemitraan yang menghubungkan banyak organisasi dan institusi di dua kota yang bermitra dapat memperkuat hubungan sister city. Luasnya partisipasi masyarakat lebih mengarah kepada tingkat keberlanjutan kemitraan yang lebih tinggi (UNDP, 2000). Partisipasi masyarakat mulai dari pemerintah daerah, lembaga sosial masyarakat, hingga sektor bisnis dari masing masing kota yang bermitra menjadi kriteria penting dari kemitraan yang sukses (Tjandradewi \& Marcotullio, 2009). Beberapa contoh kemitraan berbasis masyarakat yang sukses, diantaranya Cape Town (Afrika Selatan) dan Aachen (Jerman), serta Honolulu (Hawaii) dan Hue (Vietnam) (M. C. Bontenbal, 2009; M. Bontenbal \& Van Lindert, 2008; J. C. De Villiers, 2009).

Bebasnya arus informasi dan komunikasi yang handal dan teratur dapat meningkatkan kepercayaan dan keeratan hubungan persahabatan antara anggota dari kedua kota yang bermitra (Jacobus Christiaan De Villiers, 2011; Tjandradewi \& Marcotullio, 2009). Komunikasi yang terpelihara hingga setelah kemitraan selesai mampu memberikan peluang untuk kemitraan yang lebih lanjut. Selain itu, adanya hubungan timbal balik dinyatakan oleh pemerintah lokal sebagai faktor yang 
sangat penting untuk mewujudkan kemitraan sister city yang sukses (Tjandradewi \& Marcotullio, 2009). Kondisi tersebut dapat terwujud melalui pertukaran rutin secara jangka panjang yang menunjukan perasaan saling percaya sensitivitas terhadap perbedaan budaya, dan sikap positif terhadap resiko (J. C. De Villiers, 2009).

\section{Metode Penelitian}

Untuk memeriksa sejauh mana kemitraan sister city berkontribusi terhadap pengelolaan kota, kami melakukan penelitian kualitatif dengan menggunakan pendekatan studi kasus. Kota Surabaya dipilih sebagai kasus studi karena kinerja kemitraan sister city-nya berkontribusi terhadap pembangunan kota yang berkelanjutan dengan mengajak seluruh pihak masyarakat. Kinerja ini diapresiasi di tingkat internasional dengan diperolehnya penghargaan City to City Awards dari CITYNET di tahun 2012. Upaya investigasi terhadap faktor-faktor kesuksesan kemitraan sister city dilakukan melalui wawancara mendalam terhadap 12 informan kunci yang dipilih berdasarkan kriteria, yaitu aktor yang terlibat dalam proses dan berinteraksi dengan para pelaku dari kedua kota yang bermitra, baik dari pihak pemerintah maupun non-pemerintah. Selanjutnya, para informan berikutnya dipilih berdasarkan rekomendasi dari informan sebelumnya yang memiliki hubungan dan memenuhi kriteria (snowball). Dalam analisis, kami pertama kali menyortir data yang relevan dan mengklarifikasi informasi yang diperoleh dari sumber yang berbeda. Kemudian, analisis dilanjutkan dengan mengivestigasi sejauh mana faktor faktor yang berpengaruh sehingga kemitraan sister city dapat berkontribusi terhadap pengelolaan kota melalui proses pengkodean dan analisis isi (content analysis).

\section{Hasil dan Pembahasan}

Surabaya merupakan kota terbesar kedua di Indonesia yang berperan sebagai pusat perdagangan, bisnis, dan industri skala nasional. Skema kemitraan sister city mulai dilakukan Surabaya sejak tahun 1992 berdasarkan hubungan diplomatik Indonesia dengan beberapa negara di dunia. Hingga 2013, Surabaya memiliki tujuh mitra sister city yang diresmikan melalui Memorandum of Understanding (MOU) Sister city Cooperation, yaitu Seattle - USA (1992), Busan - Korea ( 1994), Kochi - Jepang (1997), Guangzhou - Cina (2005), Xiamen, Cina (2006), Varna - Bulgaria (2010), dan Kitakyushu - Jepang (2012). Indikasi kesuksesan kemitraan sister city Surabaya ditunjukan dengan terlaksananya berbagai proyek dan kegiatan kemitraan sister city yang mengarah pada pembangunan dan perbaikan kota secara fisik maupun nonfisik. Sebagaimana dapat dilihat pada Tabel 1, kemitraan sister city Kota Surabaya dilaksanakan secara konsisten sejak tahun 1995 melalui berbagai kegiatan dan proyek pembangunan. Di sektor pendidikan dan budaya, kemitraan dilaksanakan melalui pertukaran pengetahuan dan budaya, seperti kegiatan pelatihan, seminar, kunjungan sekolah, beasiswa pendidikan, dan festival budaya tahunan. Sementara itu, kemitraan di sektor lingkungan dilaksanakan melalui transfer pengetahuan dan teknologi. Beberapa teknologi tersebut, antara lain keranjang kompos (disebut Takakura Home Method), alat pemilah sampah di Super Depo Suterejo, dan alah pengolah sampah air. 
Tabel 1 Implementasi Kemitraan Sister city Kota Surabaya Tahun 1995 - 2013

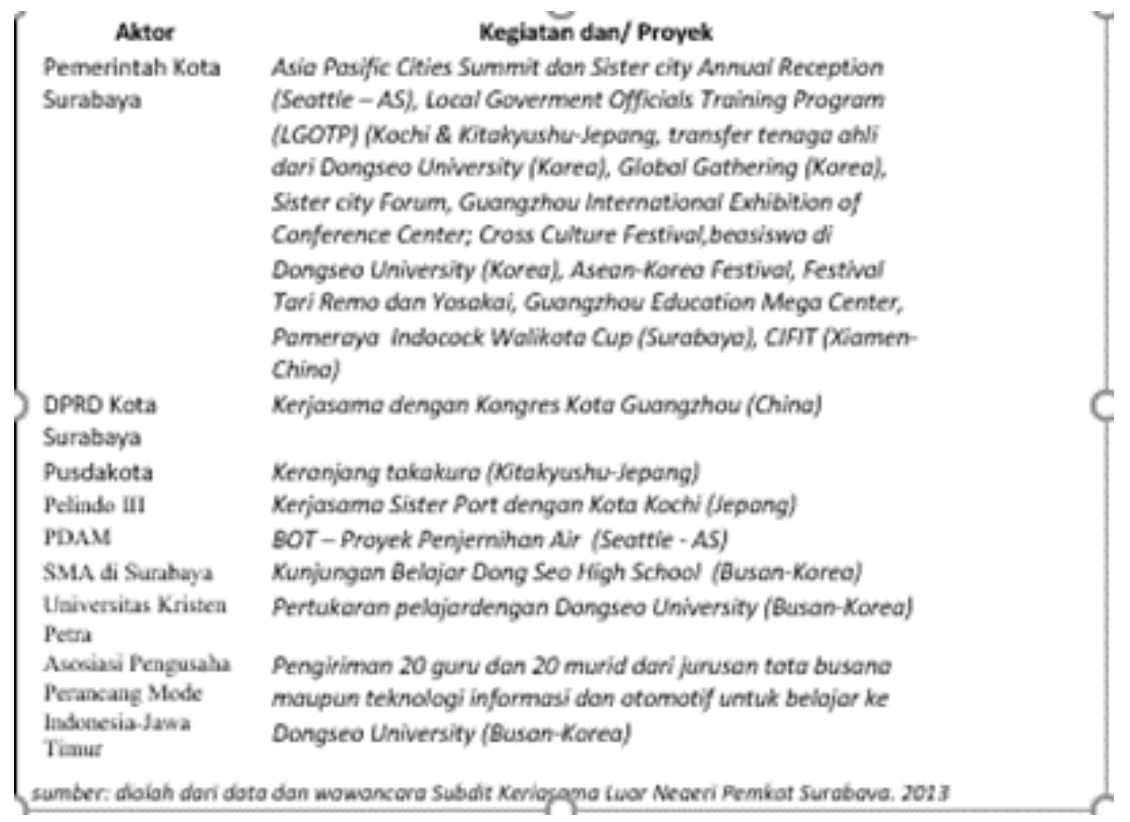

egiatan yang dilaksanakan melalui kemitraan sister city mengarah pada peningkatan kapasitas aparatur pemerintah, tenaga pengajar, dan siswa, serta memicu kreativitas masyarakat melalui penciptaan tarian tradisional yang mengkolaborasikan kebudayaan kedua kota. Secara tidak langsung, kondisi ini mendorong daya saing sumber daya lokal dan mendorong perluasan pasar pariwisata hingga ke tingkat internasional. Selain itu, pemanfaatan teknologi mampu mengurangi limbah kota di Surabaya Kemitraan sister city sukses dimanfaatkan Pemerintah Kota Surabaya sebagai strategi untuk mendorong pembangunan kota yang berkelanjutan yang dibuktikan dengan diperolehnya penghargaan internasional dan nasional, khususnya dalam bidang perubahan iklim dan MDGs, pada tahun 2013.

Kesuksesan Kota Surabaya dalam membangun jejaring kota - kota di tingkat internasional dipengaruhi beberapa faktor. Namun, sejauh mana faktor - faktor tersebut berpengaruh sehingga berkontribusi terhadap pengelolaan kota akan dijelaskan pada bagian selanjutnya.

Membangun Kepentingan Bersama

Kami menemukan bahwa bukan hanya komunikasi yang handal dan bebasnya arus informasi yang dapat meningkatkan keeratan hubungan persahabatan antara anggota dari kedua kota yang bermitra (Jacobus Christiaan De Villiers, 2011; Tjandradewi \& Marcotullio, 2009), tetapi dibangunnya kepentingan bersama melalui proses dialog dan juga keberadaan tim khusus yang berperan mengelola kemitraan sister city yang dibentuk di Kota Surabaya sejak tahun 2010. Tim ini berperan melakukan pertukaran informasi, kajian dan analisis, serta koordinasi teknis. Keberadaan tim ini memudahkan dibangunnya konsensus yang mengakomodasi kepentingan pihak - pihak yang bermitra. Adanya kepentingan bersama yang dibangun melalui konsensus/dialog menjadikan hubungan kemitraan lebih kuat sehingga tujuan kemitraan terarah dan dapat ditindaklanjuti secara langsung ke dalam 
bentuk kegiatan maupun proyek bersama.

Kepentingan bersama mulai dibangun pemerintah kota (Pemkot) Surabaya sejak proses penjajagan untuk memilih mitra. Melalui SubBagian Kerjasama Luar Negeri, Pemkot Surabaya berperan aktif dalam bertukar informasi dengan mitra melalui pihak KBRI yang berlokasi di calon kota mitra, terutama terkait dengan profil kota mitra. Kemudian, informasi ini dianalisis untuk menemukenali potensi sektor atau bidang yang akan dikerjasamakan. Selain itu, Pemkot Surabaya juga memilih kota mitra yang potensial memberikan solusi terhadap masalah kota dan mampu mendorong percepatan pembangunan kota sehingga informasi terkait pengalaman kota mitra menjadi hal yang dikomunikasikan pemkot Surabaya. Proses mencapai sebuah kesepakatan bersama membutuhkan waktu yang cukup panjang, tetapi adanya sikap saling pengertian, komunikasi yang terbuka, dan pembagian peran yang jelas memudahkan proses dialog/negosiasi sehingga mampu menghasilkan konsensus bersama.

"kita ga ada background environment sama sekali, tapi kita mengajukan prasyarat ketika melakukan kerjasama. Akhirnya ada keranjang takakura, model pengelolaan kompos yang baru ... kita sampaikan riset-riset kita yang awal kita apa saja, mereka sudah ahli, ya akhrinya menemukan formula-formula. ya pokoknya cara kami lokal. jadi supaya kita mandirilah." (Pusdakota Ubaya, April 2013)

Penyepakatan kerjasama dilaksanakan oleh para pemimpin kota sebagai pengambil keputusan secara tatap muka melalui pertemuan, baik yang dilaksanakan oleh pemerintah kota mitra maupun pemerintah kota Surabaya, dengan juga melibatkan pihak - pihak lain yang terlibat dalam kegiatan yang akan dikerjasamakan, seperti akademisi (tenaga ahli) dan pihak perusahaan swasta. Namun, komunikasi dan koordinasi teknis secara rutin juga dilaksanakan oleh SubBagian Kerjasama Luar Negeri Pemkot Surabaya dengan Tim Teknis Pemkot Kota Mitra sehingga hubungan antar kedua kota lebih erat.

Dalam prosesnya tersebut,

kedekatan wilayah juga mempengaruhi

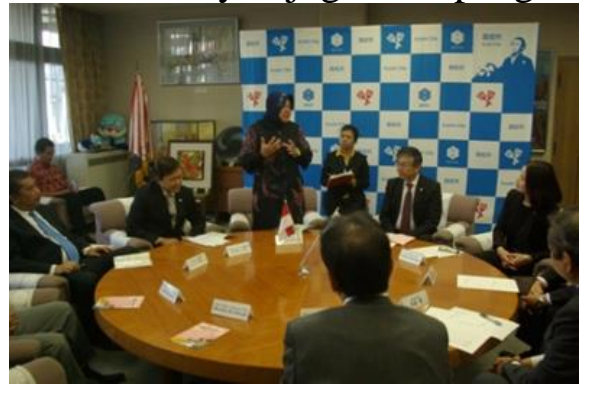

intensitas komunikasi, dimana kota

Gambar 1 Konsensus Tindak Lanjut Kemitraan Sister city

Sumber: Subbagian Kerja Sama Luar Negeri Kota Surabaya, 2013

mitra yang lokasinya jauh dan memiliki perbedaan waktu yang signifikan cenderung tidak menghasilkan kegiatan yang nyata.

Sementara itu, kami menemukan juga bahwa kesamaan karakteristik tidak berpengaruh terhadap kemudahan mencapai kesepakatan bersama dan kesuksesan kemitraan, tetapi dipengaruhi oleh adanya potensi atau kemampuan kedua pihak yang saling melengkapi atau memenuhi kebutuhan kota (J. C. De Villiers, 2009; GomesCasseres, 1998) sehingga kemitraan yang dibangun berpotensi menguntungkan kedua kota. Seperti terjadi pada kemitraan antara Kota Surabaya dan Kota Kitakyushu, dimana keduanya memiliki tujuan untuk mewujudkan kota berwawasan lingkungan. Kemitraan dibangun karena kota Kitakyushu telah berhasil mampu mengatasi pencemaran kota akibat 
limbah cair perusahaan. Kemudian, pengalaman Kota Kitakyushu tersebut menjadi pembelajaran bagi Kota Surabaya sehingga dilaksanakan transfer pengetahuan dan teknologi yang disesuaikan dengan kebutuhan Kota Surabaya.

\section{Mendorong dan Memfasilitasi Tindak Kolektif}

Kepemimpinan yang berpengaruh terhadap kesuksesan kemitraan sister city Kota Surabaya didefinisikan sebagai suatu kemampuan pemimpin lokal mendorong tindak kolektif masyarakat untuk mencapai tujuan bersama, sebagaimana dijelaskan oleh Stimson (2009). Terjadinya tindak kolektif dapat dilihat dari luasnya partisipasi masyarakat, baik pemerintah, akademisi, swasta atau asosiasi pengusaha, lembaga swadaya masyarakat (LSM), dan masyarakat, seperti dapat dilihat pada Tabel 1. Luasnya partisipasi masyarakat menjadi kriteria kesuksesan kemitraan sister city (Tjandradewi \& Marcotullio, 2009), dan eksistensinya berpengaruh juga terhadap implementasi program/kegiatan kemitraan itu sendiri di Kota Surabaya. Sebagaimana dapat dilihat pada Gambar 2, masifnya penggunaan teknologi yang di transfer dari mitra oleh masyarakat Surabaya mampu mendorong hubungan kemitraan yang jangka panjang dan meningkatkan kepercayaan mitra.

Terjadinya tindak kolektif dipengaruhi oleh konsistensi walikotanya dalam memelihara dan mengembangkan kemitraan sister city selama hampir 20 tahun meskipun mengalami tiga periode kepemimpinan yang berbeda. Kemitraan yang telah dijalin oleh walikota sebelumnya terus dievaluasi, dikaji, dan dipelihara, bahkan terus dikembangkan selama kemitraan yang dijalin menunjukan kinerja yang baik.

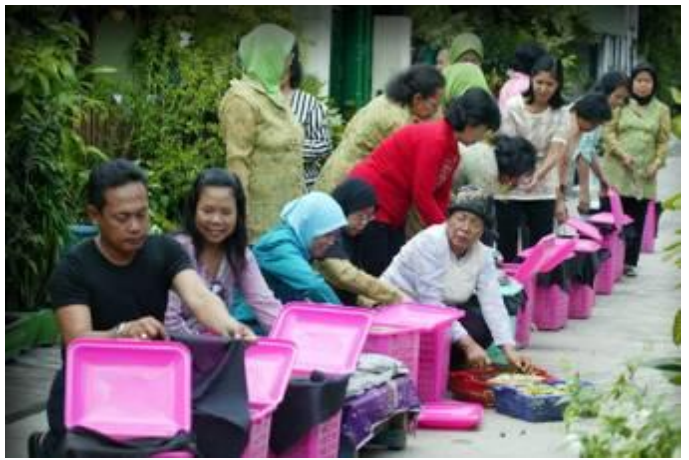

Gambar 2 Partisipasi Masyarakat dalam Pemanfaatan Keranjang

Takakura

Sumber: Dinas Kebersihan dan Pertamanan Kota Surabaya, 2013

Walikota Surabaya memiliki keeratan hubungan dengan berbagai komponen masyarakat (baik masyarakat sipil, swasta, dan LSM) dan mampu memeliharanya, dimana walikota rutin berinteraksi langsung dengan masyarakat dan memberdayakan masyarakat dalam pelaksanaan program - programnya. Misalnya, dalam program pemeliharaan lingkungan, pemkot Surabaya telah memiliki kader lingkungan yang aktif mengelola Bank Sampah yang kemudian memberikan keuntungan bagi masyarakat melalui pengolahan sampah menjadi pupuk dan kerajinan tangan. Walikota Surabaya mendorong tindak kolektif melalui penyediaan wadah atau media, seperti seminar, lomba, pameran, workshop, yang mengundang dan melibatkan berbagai komponen masyarakat. Pada akhirnya, potensi yang dimiliki masyarakat Surabaya mampu dioptimalkan dan diberdayakan oleh mitranya. Artinya, ada keahlian, pengalaman, dan hasil nyata atau keberhasilan dari Kota Surabaya yang menjadi pembelajaran bagi pihak dari kota mitra, sebagaimana dikutip pada hasil wawancara dengan akademisi dari perguruan tinggi di Kota Surabaya. 
Pemkot Surabaya dalam setiap program atau kegiatannya.

\section{Menciptakan Hubungan Timbal Balik}

Hubungan timbal balik sumber daya yang seimbang dengan kota mitranya. Artinya, ada keahlian, pengalaman, dan hasil nyata atau keberhasilan dari Kota Surabaya yang menjadi pembelajaran bagi pihak dari kota mitra, sebagaimana dikutip pada

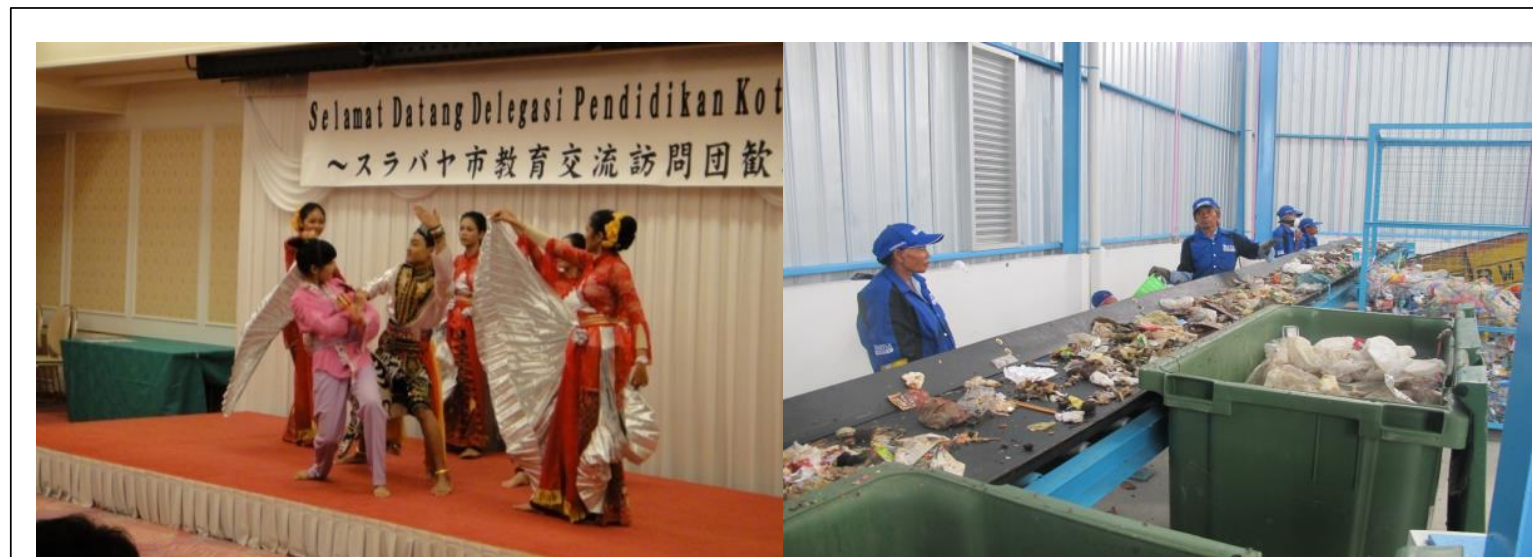

(1) Pertukaran Delegasi Pendidikan

(2) Pabrik Pemilah Sampah (Superdepo Suterejo)

Gambar 3 Implementasi Kemitraan Sister city Kota Surabaya

antara kedua kota yang bermitra dan kedua pihak menerima hasil dan manfaat dari terjalinnya kemitraan sister city. Hubungan timbal balik secara jangka panjang mampu meningkatkan kepercayaan mitra (J. C. De Villiers, 2009). Pemkot Surabaya mampu menciptakan hubungan timbal balik melalui komitmennya mengalokasikan anggaran daerah (APBD) untuk program kemitraan sister city. Selanjutnya, hasil dari program tersebut ditindaklanjuti oleh Pemkot Surabaya menjadi suatu program atau kegiatan pembangunan di Kota Surabaya. Contohnya, program pembangunan instalasi pengolahan limbah cair. Selain itu, Pemkot Surabaya juga mengoptimalkan peran serta dari pihak swasta, seperti media publikasi atau perusahaan swasta melalui dana CSR (Coorporate Social Resposibility)nya sebagai sponsor kegiatan. menunjukan tidak adanya ketergantungan kepada salah satu pihak. Kota Surabaya memiliki kemampuan hasil wawancara dengan akademisi dari perguruan tinggi di Kota Surabaya. "Jadi banyak orang Kitakyushu yang akhirnya dikirim kesini untuk belajar dari Surabaya dan banyak juga ahliahli Surabaya yang dilatih dan dididik di Kitakyushu ya." (Dosen Institut Teknologi Sepuluh November, April 2013)

Kota Surabaya memiliki prestasi, terutama dalam pembangunan di bidang lingkungan dan pemberdayaan masyarakat. Hasil dari program pembangunan tersebut juga diakui baik secara nasional maupun internasional. Selain itu, beberapa program kemitraan sister city juga telah dilaksanakan secara partisipatif. Hal ini menjadi keutamaan yang dimiliki Kota Surabaya. Selain itu, hasil program kemitraan sister city telah memberikan manfaat bagi kota mitra karena teknologinya yang telah digunakan secara masif oleh masyarakat Kota Surabaya. Kondisi ini mampu meningkatkan kepercayaan kota mitra 
Bontenbal, M. C. (2009). Strengthening

\section{Kesimpulan}

Jejaring kota - kota secara global yang dibangun melalui kemitraan sister city sukses digunakan oleh pemerintah lokal sebagai strategi pengelolaan kota yang berfokus pada proses pembelajaran dan pertukaran, serta transfer pengetahuan dan teknologi. Jejaring sister city yang dimiliki Kota Surabaya telah mampu berkontribusi terhadap pengelolaan kota. Kesuksesan tersebut diukur melalui pendekatan hasil, dimana program kemitraan yang dilaksanakan telah mengarah pada peningkatan kapasitas sumber daya manusia di tingkat lokal, membantu mengurangi masalah pengelolaan lingkungan kota, serta memicu peningkatan peluang pasar dan daya saing global.

Faktor kesuksesan kemitraan sister city di Kota Surabaya yang berkontribusi besar terhadap tujuan pembangunan cenderung didorong oleh hubungan timbal balik yang terjadi diantara dua kota yang bermitra. Untuk mampu menciptakan hubungan timbal balik, komitmen pemimpin lokal atau aktor dalam alokasi pendanaan, keseimbangan kemampuan atau potensi yang dimiliki dua kota yang bermitra, serta adanya pengalaman keberhasilan dalam implementasi suatu program kemitraan dibutuhkan. Dengan demikian, kemitraan tersebut diisi oleh program dan kegiatan rutin secara terus - menerus sehingga terjalin hubungan jangka panjang yang mengarah pada tujuan pembangunan.

Kesuksesan kemitraan sister city juga didorong oleh hubungan jangka panjang yang dipelihara oleh para pemimpin lokal. Dalam hal ini, konsistensi kepemimpinan lokal terhadap pelaksanaan kemitraan sister city dibutuhkan meskipun terjadi perubahan aktor atau pemimpin di dalamnya. Untuk menunjang hal tersebut, keberadaan bagian atau tim khusus yang mengelola kemitraan sister city mampu menjaga komunikasi, menstimulus pertukaran informasi, memudahkan koordinasi, serta memastikan keefektifan program atau kegiatan kemitraan, terutama pada saat jejaring sister city tersebut semakin luas.

Sementara itu, kepentingan bersama yang dibangun melalui proses dialog dan luasnya partisipasi cenderung tidak berpengaruh secara langsung terhadap kesuksesan kemitraan sister city. Faktor - faktor tersebut lebih mengarah pada kebutuhan atau prasyarat dari suatu proses pembangunan dan hubungan kemitraan yang baik. Meskipun keberadaannya dapat membuat hubungan kemitraan lebih kuat.

\section{DAFTAR PUSTAKA}

Bontenbal, M. C. (2009). Strengthening urban governance in the South through city-to-city cooperation: Towards an analytical framework. Habitat International, 33(2), 181189.

Bontenbal, M., \& Van Lindert, P. (2008). Bridging local institutions and civil society in Latin America: can city-tocity cooperation make a difference? Environment and Urbanization, 20(2), 465-481.

De Villiers, J. C. (2009). Success factors and the city-to-city partnership 
management process-from strategy to alliance capability. Habitat International, 33(2), 149-156.

De Villiers, Jacobus Christiaan. (2011). Strategic alliances between communities, with special reference to the twinning of South African provinces, cities and towns with international partners ( $\mathrm{PhD}$ Thesis). Stellenbosch: University of Stellenbosch.

Gomes-Casseres, B. (1998). Do you really have an alliance strategy. Strategy \& Leadership, 26(4), 6-11.

Hafteck, P. (2003). An introduction to decentralized cooperation: definitions, origins and conceptual mapping. Public Administration and Development: The International Journal of Management Research and Practice, 23(4), 333-345.

Keating, M. (1991). Comparative urban politics: Power and the city in the United States, Canada, Britain, and France. Aldershot, England: E. Elgar.

Kurniawan, T. A., de Oliveira, J. P., Premakumara, D. G., \& Nagaishi, M. (2013). City-to-city level cooperation for generating urban co-benefits: the case of technological cooperation in the waste sector between Surabaya (Indonesia) and Kitakyushu (Japan). Journal of cleaner production, 58, 43-50.
LGIB, L. G. I. B. (2001). The links effect: a good practice guide to transnational partnerships and twinning of local authorities. LGIB International report number 3.

O'Toole, K. (2001). Kokusaika and internationalisation: Australian and Japanese sister city type relationships. Australian Journal of International Affairs, 55(3), 403-419.

Roldan, M. D. G. Z. (2018). Local Governments as International Players: Examining Town Twinning as a Mechanism.

Salam, U. (2004). Dinamika Kerjasama Internasional Provinsi di Indonesia dengan Luar Negeri. Makalah. Dipresentasikan pada Lokakarya Cara Penanganan Kerjasama Internasional.

Stimson, R. J., Stough, R., \& Salazar, M. (2009). Leadership and institutions in regional endogenous development. Edward Elgar Publishing.

Tjandradewi, B. I., \& Marcotullio, P. J. (2009). City-to-city networks: Asian perspectives on key elements and areas for success. Habitat International, 33(2), 165-172.

UNDP. (2000). The challenges of linking. New York: United Nations Development Programme.

Zelinsky, W. (1991). The twinning of the world: sister cities in geographic and historical perspective. Annals of the Association of American Geographers, 81(1), 1-31. 